\title{
LAND GRABBING OR RICE SECTOR DEVELOPMENT OPPORTUNITY? THE CASE OF WANBAO PROJECT IN GAZA, MOZAMBIQUE
}

\author{
Sérgio Ponguane*, Bento Mussumbuluco, Nézia Mucavele \\ Divisão de Economia e Gestão, Instituto Superior Politécnico de Gaza (ISPG), Mozambique. \\ ${ }^{*}$ Corresponding author: ponguane@yahoo.com.br
}

Citation: Ponguane., Mussumbuluco, B., and Mucavele, N. 2021. Land Grabbing or Rice Sector Development Opportunity? The Case of Wanbao Project in Gaza, Mozambique. J. Asian Rur. Stud. 5(2): 135-142

\begin{abstract}
Demand for agricultural land by foreign investors has been increasing in Mozambique over the last years and the Wanbao project is an example. The implementation of this project in Gaza has divided opinions between the government, civil society and academia. This study aims to contribute to the debate on whether Wanbao project can be considered as land grabbing and the extent to which the project contributes to the development of small-scale agriculture in Gaza Province. Data were collected through a semi-structured questionnaire in December 2019 and January 2020, covering a total of 66 household affected by the Wanbao project. The data were analyzed by a descriptive statistic and a cross-check of the Mozambican land law, the available literature on land grabbing and the information collected on the ground from the farmers affected by the project. The results show that the land concession to Wanbao was made without any consideration of customary rights, however, it was found that the contract farming program can increase rice productivity in the short term, but its sustainability remains questionable. Thus, if the Mozambican government intends to transform agriculture through large investments, it must ensure that the concession of land respects customary rights and the companies involved ensure the transfer of technologies in an effective and sustainable manner.
\end{abstract}

Keywords: Land Grab; Agricultural Investment; Wanbao Project; Xai-Xai Irrigation; Mozambique

\section{Introduction}

Agriculture is the backbone of the Mozambican economy, contributing a quarter of the gross domestic product and providing livelihoods for more than $75 \%$ of the population (Mosca, 2017). According to the Ministry of Agriculture and Rural Development, Mozambique has 36 million hectares of arable land including an irrigation structure for more than 3 million hectares, however, despite this potential, Mozambican agriculture continues to be dominated by smallholder farmers and characterized by low use of improved agricultural technologies and hence, low productivity. Guanziroli and Guanziroli (2015) state that the average yield of staple crops in Mozambique is between one fifth and half of the world average productivity.

Seeking solutions to the problems of low adoption of agricultural technologies and low productivity, the government of Mozambique has adopted several strategies and policies, including the Green Revolution Strategy (GRS), which is a multidimensional strategy approved in 2007 to fight hunger and poverty. In order to implement the GRS, the government launched in 2010 the Strategic Plan for the Development of the Agrarian Sector 
(PEDSA), which is founded on Vision 2025 and is based on national guidelines for agriculture and the priorities defined in the Comprehensive Africa Agriculture Development Programme (CAADP) whereby heads of states agreed to allocate $10 \%$ of the national budget for agricultural development to ensure an annual growth rate of $6 \%$ (NEPAD, 2016). One of PEDSA's objectives is to increase agricultural production and productivity and its competitiveness, for this end, the plan focuses essentially on mobilizing investment for the agricultural sector (MINAG-Pedsa, 2011).

Four years after the Maputo Declaration, the world food crisis forced western countries and China to seek production alternatives across borders. The African continent holding $60 \%$ of the world's agricultural land (Mzali, 2019) was one of the main destinations for large investments (GRAIN, 2015; Hallam, 2009) with about 422 closed deals in a total area of ten million hectares (Nolte, Chamberlain and Giger, 2016). The government of Mozambique has been developing mechanisms that aim to stimulate agricultural investment either through public funds with favorable interest rates or through land concessions for large foreign investments. These efforts coincided with the massive demand for agricultural land making the country one of the main foreign investment destinations in the agricultural sector. Since the global food crisis, the number of agricultural investments has more than doubled, with $72 \%$ of agricultural investments coming from just five countries (Di Matteo and Schoneveld, 2016).

In 2007, the provinces of Hubei, China and Gaza, Mozambique signed a memorandum to grant 300 hectares of land to Chinese entrepreneurs to serve as a demonstration field and technology transfer center for rice production for small local producers (Bräutigam, 2015; Chichava et al., 2013) which would be formally established giving rise to the Hubei-Gaza Friendship Farm. Hubei Lianfeng Mozambique Co, Lda, the company responsible for technology transfer was unable to successfully implement what had been established in the memorandum, having passed its management to a private Chinese company, Wanbao Africa agriculture Development Limited (WAADL) in 2012. WAADL was granted by the Gaza provincial government 20 thousand hectares of arable land, a quarter of the Xai-Xai irrigation scheme. The implementation of this project sparked a huge popular uprising in 2013, in part because China's huge investment in Gaza coincided with the 2008 food crisis, this has raised enormous speculation within Sino-Mozambican relations including in the agricultural sector. Some researchers and analysts were suspicious that China has been involved in transactions that involved land grabbing in Africa to produce food then ship back to China and not for the benefit of the local community.

There are two competing theories in the analysis of this type of investment, one that looks at this model as a way that worsens the situation of small holder farmers since its implementation means transferring their means of production (land and water) to a relatively small group that includes political elites and private investors generally rich in capital (Ganho, 2013a), and the other that argues that this model fits in the context of win-win investment model, because investment in agriculture means jobs creation for the local community, infrastructure rehabilitation and technology transfer making small-scale agriculture more competitive (Bräutigam \& Xiaoyang, 2009; Bräutigam \& Zhang, 2016).

Di Matteo and Schoneveld (2016) noted that there is need to understand the peculiar characteristics of each type of external agricultural investment given the diversities of such investments, and not just limit the analysis on generalization of agricultural investment patterns in different regions. For these authors, the success of adopting the right models will depend on the environment and circumstances under which each investment takes place. In fact, it is in this context that Bräutigam (2015) argues that contrary to what is written, sometimes without a scientific basis, the Wanbao project does not aim to produce rice to 
"feed" the Chinese, but rather to help the country reduce the food deficit through greater rice production and productivity.

The Wanbao project has been subject of heated debate between civil society and political parties, some believe that the project is one more case of land grabbing while others believe that this is an example of well succeeded Chinese agricultural investment overseas and a unique opportunity to transform the family farming sector in Gaza. There is no consensus on whether Wanbao is a land grab type or not. Furthermore, a dearth of scientific studies aiming to understand the subject in greater depth exists, therefore, this study aims to answer the following questions: Could the Wanbao project be considered a type of land grabbing or not? Does the project contribute to the development of family farming through technology transfer in the region?

\section{Methods}

The study was carried out in Gaza province, specifically in the districts of Limpopo and Chongoene, located in the southern part of the province. The districts of Limpopo and Chongoene originated from the division of the former district of Xai-Xai located just over $200 \mathrm{~km}$ north of the capital Maputo. The province is crossed by the Limpopo River, a vital water resource for agricultural and livestock development. It is where the irrigation scheme of the lower Limpopo (Regadio do Baixo Limpopo) with 70000 hectares of land is located.

Data were collected through a semi-structured questionnaire in December 2019 and January 2020, covering a total of 66 household affected by the Wanbao project. Seven of these farmers benefit from the technology transfer program for rice production offered by Wanbao. In addition, in July 2020 we conducted interviews with senior staffs from the Regadio do Baixo Limpopo, EP (RBL-EP), a public company created in 2010 to manage the Lower Limpopo Irrigation scheme which includes the fields allocated to Wanbao (EEA, 2019; Ganho, 2013b). The number of affected farmers is unknown, some organizations state that around 70 thousand farmers were affected by the project (Madureira, 2014), however these figures may be overestimated. According to the officials from RBL, the overestimation of affected farmers aims to attract the attention of organizations that fight against land grabbing although they were not able to disclose their estimates of affected farmers. The Wanbao project was granted 20,000 hectares from the provincial government of Gaza, an area equivalent to more than $25 \%$ of the 70,000 hectares under the management of the Lower Limpopo Irrigation (RBL). The area includes fields located in Chicumbane, Xai-Xai, Magula and Chimbonhanine (Ganho, 2013b; Madureira, 2014), however, only 8300 hectares are equipped and are being effectively exploited.

Given the limitations described above, the study used the non-probabilistic sampling technique in the communities of Chicumbane, Inhamissa and Chimbonhanine, where affected farmers who were willing to respond were surveyed. For data analysis, a descriptive statistics and a cross-check of the Mozambican land law, the available literature on land grabbing and the information collected on the ground from the farmers affected by the project and RBL officials were used. It was not possible to interview the Wanbao officials because they were in China for the celebration of the Chinese New Year where they would later be held up as a result of the suspension of flights and closure of borders due to the Covid-19 pandemic.

\section{Results and Discussion}

The 2008 food crisis is pointed out by some researchers as the starting point for the "boom" of the phenomenon of land grabbing. Since the publication of Seized by GRAIN, the phenomenon of land grabbing has been subject of several studies, mainly due to its negative 
consequences for rural communities whose land is the solely asset for survival. Land grabbing can be defined in several ways, from fraudulent appropriation to large foreign investments in agriculture, but to make justice to the first question of the present work, the study applies the definition proposed by Eco Ruralis, a Romanian NGO with a thousand members, whose mission is to support agro ecology and promote small-scale family farming as the dominant and preferable method of agriculture.

Eco Ruralis takes into account five dimensions for the definition of land grabbing. For this organization, it is necessary to take together aspects related to the size of the transacted land, the people involved in the process, the control of the land, the legal framework and the purpose of the appropriation. The criteria using these dimensions should take into account the actual situation of each country and the data available. Thus, land grabbing can be defined as control either through ownership, lease, concession or contracts of areas larger than locallytypical amounts by any person or entity (public, private, local or external) by any means, whether legal or illegal for the purpose of extraction or production at the expense of local communities, agro ecology, food autonomy and human rights.

The Wanbao project was analyzed in the light of this definition to determine whether or not it can be classified as land grabbing. The Mozambican government has granted Wanbao 20,000 hectares of land for a period of 50 years; based on the definition above, it can be seen that the government has granted amounts that exceed the locally-typical amounts to a foreign company. The typical local average in Mozambique is less than 10 hectares and represents $98 \%$ of all farms, the other farms, generally those with more than 50 hectares, represent less than 1\% (MASA, 2016; Mosca, 2017). Thus, it can be concluded that the control and size dimensions in this concession fall in the land grabbing category. In addition, it worth revisiting the Mozambican Land Law to verify whether or not this concession complied with the legal instruments in the country.

Article 11 of the Land Law states that:

Individuals and foreign legal persons may be subject to the right to use and benefit from the land, provided that they have an approved investment project and observe the following conditions: a) being individuals, provided that they have resided for at least five years in the Republic of Mozambique; b) being legal persons, provided that they are incorporated or registered in the Republic of Mozambique,

On the other hand, article 12 of the same document states that:

The right to use and benefit from land is acquired by: a) occupation by individuals and local communities, according to customary rules and practices that do not contravene the Constitution; b) occupation by national individuals who, in good faith, have been using the land for at least ten years; c) authorization of an application submitted by individuals or legal persons in the manner established in this Law.

Thus, it seems clear that both Wanbao and the community have the right to use and benefit from land in Mozambique, however there is need to ensure that large scale land deals with foreign investors do not mean deprivation of rights to the local community. Furthermore, article 18 of the Land Law states that land title holders can loss their rights provided that, among others, the exploitation plan is not fulfilled, there is need to implement projects of public interest, expiry of the term and/or resignation of the titleholder. It is under these circumstances that the Mozambican Land Law gives room to land grabbing. According to the officials of RBL, EP, the land granted to Wanbao did not belong to the community, rather it was part of the former state machambas and was not under exploitation, for this reason it was allocated to Wanbao without the need for compensation such as the law provides for when 
loss of rights occurs for reasons of public interest. This information contradicts what was found on the ground. Based on the data from the study, it was found that out of 66 surveyed farmers, 55 or $83.33 \%$ declared that at the time of occupation of their fields they were producing and saw their crops being destroyed by the bulldozer of Wanbao and $71.21 \%$ had not received any compensation while $28.79 \%$ confirmed that they had received other pieces of land, but relatively smaller and less productive. The data show that the pieces of land granted to Wanbao were of 1.5 hectares on average while those received were on average 1.1 hectare. Only $12 \%$ declared that they had had prior notice from the government claiming that the land would be set aside for reasons of public interest, while another $4 \%$ would have been informed that they lost their land titles for not having complied with the exploitation plan.

In fact, titleholders may lose their rights for non-compliance with the exploitation plan in cases where land is acquired for the purpose of economic activities (this is not applicable to customary right holders), however, only 11 out of 66 farmers, or $16 \%$ of the respondents stated that at the time of the occupation of their land were not producing, allegedly due to lack of financial means and flooding of their fields under the 2013 floods, furthermore, none of interviewed farmers had acquired land for economic activities-they are customary right holders. It is worth mentioning that, article 13 of the Land Law states that the process of land titling to foreign investors includes the opinion of local administrative authorities, preceded by consultation with communities, for the purpose of confirming whether the area is free and has no occupants, which did not happen in the case of Wanbao. RBL officials confirm that there was no such consultation and the reasons remain the same as previously presented. This suggests that the argument that there is extensive idle land that should be granted to those who have financial means and are able to produce for the benefit of everyone is recurrently used to justify transactions often to the detriment of local communities and without observation of legal framework

Cotula et al. (2009) argues that expressions such as available land, idle or wasted land often used to justify land concessions to foreign investors should be carefully analyzed. In this case, it was evident that the process of land concession to Wanbao based on the same argument was conducted without negotiation or prior notice, in addition to not providing adequate compensation for those affected by the project. Although the issue of legality in the concession of land is not decisive to assess whether or not a transaction can be classified as land grabbing in the definition of Eco Ruralis, it can be said that in the case under study, the legal framework aiming to preserve customary rights was not taken into account.

These results concur with the findings by Montilla Fernández (2017) arguing that land grabbing can occur legally or illegally as a result of ambiguities in some laws, which somehow seem to favor the phenomenon. The fifth and final dimension proposed by Eco Ruralis suggests that land grabbing is generally characterized by emphasizing monoculture systems, which pose a threat to the preservation of resources (water and soil) and biodiversity. Wanbao is dedicated exclusively to rice production, thus bringing together the five dimensions provided by Eco Ruralis to consider a concession as land grabbing. Contrary to what some analysts present about this project, the fact is that Wanbao can definitely be considered as land grabbing with potential negative repercussions for local communities. There is strong evidence that under this concession, the relevant measures to protect the rights of local communities have not been properly taken into account. The government is aware that land deals sometimes occur without any consideration of customary rights as the President of the Republic pointed in his speech during the official launch of the auscultation process for the revision of the National Land Policy in Mozambique. He made it clear that the recognition and protection of customary rights as well as state ownership of the land are to be maintained under the new law but changes on other aspects are needed to ensure that there is 
no idle land and that the country can respond to the challenges of market structure consolidation where demographic and economic dynamics sometimes result in conflict.

Therefore, in addition to the way the land was allocated to Wanbao, there is need to assess the results of the project at the local level. Technical efficiency has been crucial in decision making process, however, from a social point of view, besides technical efficiency an allocative efficiency is required. Although it was not possible to survey a larger number of farmers participating in contract farming, the data show that rice productivity has increased considerably. Before joining the scheme of technology transfer, interviewed farmers in Gaza produced on average 1.5 tons per hectare but currently farmers under the technology transfer program produce 7.5 tons/ ha on average.

Apart from increasing productivity, farmers have a guaranteed market, Wanbao provides all technical assistance and inputs and then buys all production leaving them only a part for consumption. According to representatives of the RBL, there are currently 513 farmers benefiting from the technology transfer program. The same source states that many farmers already explore farms of up to 5 hectares and productivity can reach 10 tons, roughly six times greater than the local average. For this reason, more and more farmers are expressing interest in participating in contract farming with Wanbao, which has led the company to rehabilitate a 1000-hectare block in Magula to allow more farmers to participate.

Despite the good results of Chinese technology in increasing productivity and the expressed interest for greater participation, there are relevant aspects that deserve attention in this project. Farmers who participate in the program depend entirely on the company for carrying out the main activities and their role in the production process remains marginal. This has been one of the reasons for the poor sustainability of Chinese interventions in african agriculture (Bräutigam \& Xiaoyang, 2009). This model persists at least in Gaza where all farmers who receive assistance from Wanbao are mainly engaged on secondary activities, while the most important, including the supply of inputs is left for the Chinese, furthermore sales prices are set by Wanbao and do not allow satisfactory returns to farmers. Company dominance and farmers' poor negotiating skills have negative implications on the long run sustainability and community empowerment through productive diversification. Farmers have little chance of developing their activities without being linked to Wanbao.

The data show that farmers under contract farming produced other crops rather than rice before the project, but currently they are only focused on rice production. This finding suggests that the entry of Wanbao has shifted farmers from diversification system to monoculture-type of production, thus blocking some possibilities for the development of agriculture for this specific group. Before the program, farmers in the region produced several crops, including maize, beans and cassava, however, when they lost their land, they either did not produce more or produced very little because the new plots were not as productive as the lost ones or because they were smaller. On the other hand, those under contract farming have started to focus on rice production only. With diversification, small farmers would obtain more income by selling their produce or obtain diversified food for their households (Sekabira and Nalunga, 2020) thus, with the practice of monoculture, not only will be subjected to greater risk but also reduce food availability for their families beyond the danger that the practice of monoculture can pose to the soil and water.

\section{Conclusion}

The analysis of land concession to Wanbao in Gaza led to the conclusion that despite the good intentions of the Mozambican government to transform the agricultural sector from a 
predominantly subsistence regime to one that guarantees income for rural families through rice production, there are shortcomings that need to be addressed to bring peace between the project and the local community. The study found that the process occurred without proper consideration of customary rights. Although the implementation of the project derives from issues related to public interest, given that the objective advocated in the memorandum with the RBL aims to increase agricultural income and food availability for the population of Gaza province and the country in general, $71.21 \%$ of farmers whose land was given to Wanbao did not receive any kind of compensation and there was no prior negotiation between the government and the affected group. On the other hand, the technology transfer program promoted by Wanbao proved to be extremely relevant in increasing rice productivity in Gaza. Farmers participating in the program obtain on average 7.5 tonnes per hectare, a productivity well above the local average of less than 2 tonnes per hectare, however, although productivity itself does not seem to be a problem, the same cannot be said about the effective transfer of technology to the community. Wanbao, through the Chinese technicians, is in charge of all main production activities, leaving to local farmers all other secondary activities, these practices can undermine the effective transfer of technology and its sustainability. Therefore, if the Mozambican government intends to transform agriculture while protecting local farmers, it should ensure that the new National Land Policy, on which consultation are ongoing, takes into account aspects that reinforce the protection of customary rights. Finally, we suggest greater supervision of the activities carried out by companies that are granted land to assess whether the clauses set out in the memorandum are duly observed, to ensure that disadvantaged groups can take full advantages of these projects.

\section{Funding}

The study was funded by the Fundo de Pesquisa do ISPG through the Centro de Recursos Técnicos e Tecnológicos (CRTT).

\section{References}

Bräutigam, D., 2015. Will Africa Feed China? New York: Oxford University Press.

Bräutigam, D. and Zhang, H., 2016. Green dreams: Myth and reality in china's agricultural investment in Africa. Global Land Grabs: History, Theory and Method, 34(9), pp.160180.

Bräutigam, D.A. and Xiaoyang, T., 2009. China's engagement in African agriculture: 'Down to the countryside'. China Quarterly, (199), pp.686-706.

Chichava, S., Duran, J., Cabral, L., Shankland, A., Buckley, L., Lixia, T. and Yue, Z., 2013. Discursos E Narrativas Sobre O Engajamento Brasileiro E Chinês. IESE, 44(4), pp.417-438.

Cotula, L., Vermeulen, S., Leonard, R. and Keeley, J., 2009. Land grab or development opportunity? Agricultural investment and international land deals in Africa, IIED/FAO/IFAD. [online] Available at: $<\mathrm{ftp} / / / \mathrm{ftp}$.fao.org/docrep/fao/011/ak241e/ak241e.pdf $>$.

European Environment Agency (EEA), 2012. No Regadio do Baixo Limpopo. 53(9), pp.1689-1699.

Ganho, A.S., 2013a. Agro-Investimentos Privados E Seus Reflexos Na Regulamentação Fundiária E Hídrica Em Dois Regadios Estatais Em Gaza. Desafios para Moçambique, [online] p.24. Available at: 
$<$ http://www.iese.ac.mz/lib/publication/livros/des2013/IESE_Des2013_11.AgroInvPriv .pdf>.

Ganho, A.S., 2013b. LDPI Working Paper. LDPI. GRAIN, 2015. Unac and grain.

Guanziroli, C.E. and Guanziroli, T., 2015. Modernização da agricultura em moçambique: Determinantes da renda agrícola. Revista de Economia e Sociologia Rural, 53, pp.S115-S128.

Hallam, D., 2009. Foreign Investment in Developing Country Agriculture - Issues, Policy Implications and International Response. Global Forum VIII on International Investment, p.9.

Liu, P., 2014. Impacts of Foreign Investment in Developing Country Agriculture: Evidence from case studies. FAO Commodity and Trade Policy Research, (47), pp.1-23.

Madureira, M., 2014. Mega-Projectos E Transição Agrária : O Caso Do Projecto Wanbao. MASA, 2016. Anuário de Estatísticas Agrárias 2015. [online] p.66. Available at: $<$ https://www.masa.gov.mz/wpcontent/uploads/2017/12/Anuario_Estatistico2016.pdf $>$.

Di Matteo, F. and Schoneveld, G.C., 2016. Agricultural investments in Mozambique: An analysis of investment trends, business models and social and environmental conduct. Agricultural investments in Mozambique: An analysis of investment trends, business models and social and environmental conduct, (March).

MINAG-Pedsa, 2011. Plano Estrategico para o Desenvolvimento do Sector agrario de Mocambique-PEDSA. Vasa, [online] pp.1-76. Available at: $<$ http://medcontent.metapress.com/index/A65RM03P4874243N.pdf $>$.

Montilla Fernández, L.T., 2017. What Is 'Land Grabbing'. (August), pp.33-79.

Mosca, J., 2017. Agricultura familiar em moçambique: ideologias e políticas/ Family agriculture in Mozambique: ideologies and policies/ Agricultura familiar en Mozambique: ideologías y políticas. Revista NERA, 20(38), pp.68-105.

Mzali, S. (Africa R.E., 2019. Agriculture in Africa 2019. [online] Available at: $<$ https://oxfordbusinessgroup.com/blog/souhir-mzali/focus-reports/agriculture-africa2019-special-report>.

NEPAD, 2016. Guidelines CAADP Country Implementation under the Malabo Declaration. New Partnership for Africa's Development, (April).

Nolte, K., Chamberlain, W. and Giger, M., 2016. International Land Deals for Agriculture Fresh insights from the Land Matrix: Analytical Report II. Berb, Montpellier, Hamburg, pretoria: Centre for Development and Environment, University of Bern. [online] Available at: <http://landmatrix.org/media/filer_public/ab/c8/abc8b563-9d744a47-9548-cb59e4809b4e/land_matrix_2016_analytical_report_draft_ii.pdf>.

Sekabira, H. and Nalunga, S., 2020. Farm production diversity: Is it important for dietary diversity? Panel data evidence from Uganda. Sustainability (Switzerland), . 